\title{
Role of railway traffic in public urban and suburban passenger transport (example of the City of Zagreb)
}

\author{
D. Barić, D. Badanjak \& L. Novačko \\ University of Zagreb, Faculty of Transport and Traffic Sciences, Croatia
}

\begin{abstract}
One of the basic problems of all the mid-size and bigger European cities is not only the permanent increase in the demand for passenger transport services, but also the increase in individual automobile traffic. Apart from environmental pollution such urban mobility results in constant road congestion in urban areas, also endangering the safety of traffic participants. All European cities face these problems, which directly affect the quality of life of residents, attractiveness and economic development. In order to increase mobility and at the same time to reduce the congestion, traffic accidents and environmental pollution, it is necessary to reduce and limit the individual traffic in urban and suburban traffic systems, and increase the share of railway traffic, which has a series of direct and indirect comparative advantages over other traffic modes (very low harmful emissions, lower energy consumption, higher speed which allows significant savings in travel time, stimulation of suburban zones development, etc.). Therefore, the railway should have a dominant role in urban and suburban passenger transport, i.e. it should be the fundamental part of the system, which is upgraded by other subsystems. This paper studies the role and significance of the railways in public urban and suburban passenger transport in the City of Zagreb. Apart from the analysis of the existing situation on public urban transport in the City of Zagreb and the current role of the railway in the public urban transport (PUT) system, which has not been sufficiently used yet, special emphasis is given to the projection of the future role of railways in the PUT flow, including the new routes, which would along with the existing infrastructure allow the railways a greater share and a more significant role in the PUT system.
\end{abstract}

Keywords: railway traffic, public urban and suburban transport, City of Zagreb. 


\section{Introduction}

Public urban passenger transport is of extreme social interest and as such represents a significant component in the development of industry and the society in general. The City of Zagreb with its geographic location and historic role represents a significant political, cultural, scientific, tourist and economic centre, and is the origin and destination of numerous flows of goods and passengers. The City has about 800,000 citizens, and with the close surroundings exceeds a million inhabitants. The catchment area of the City of a million citizens is the origin of everyday trips to work, schools or other purposes that require frequent urban and suburban passenger rail traffic, and a large number of railway stations and stops. Because of high demand for the transport service and the constant increase in individual transport, there are inevitable congestions in traffic, implying a higher level of environmental pollution. In the existing system of public urban transport in the City of Zagreb, in spite of its comparative advantages, the railway still has no dominant role, which would be one of the preconditions of solving the existing traffic problems. One of the reasons is that the existing network of railway lines and stations has not been completely adapted to the needs of the public urban and suburban railway traffic. Therefore, it needs to be supplemented in order to raise the level of service, and thus be able to soon take over the dominant role in urban, and especially suburban public passenger transport.

\section{Public urban passenger transport in the City of Zagreb}

Public urban transport in the City of Zagreb exists as rail, tram, bus and funicular transport. The majority of the public urban transport in Zagreb is operated by the "Zagrebački električni tramvaj" - ZET (Zagreb Electrical Tram), which is the operator of the tram and bus traffic, and takes care of the funicular as well. The railway traffic operator is the Hrvatske željeznice (Croatian Railways). The total number of transported passengers per year in public urban traffic ranges is about 294,075,000 (Table 1) [3, 4].

Table 1: Annual number of transported passengers in PUT in the City of Zagreb.

\begin{tabular}{|c|c|c|c|c|}
\hline Type of PUT & Rail & Tram & Bus & Funicular \\
\hline $\begin{array}{c}\text { Number of carried } \\
\text { passengers a year } \\
\text { (year 2007) }\end{array}$ & $\begin{array}{c}27,325,00 \\
0\end{array}$ & $182,000,000$ & $84,000,000$ & 750,000 \\
\hline
\end{tabular}

\subsection{Tram traffic}

Regular tram traffic operates on $116,346 \mathrm{~m}$ of tracks, accommodating every working day in operation are 184 tram motor vehicles and 84 trailer-cars (Figure 
1). The daily number of tram lines is 15 , and they operate on a total of $148 \mathrm{~km}$ of tracks. Four are night lines, which operate on the network length of $57 \mathrm{~km}$. There are 167 turnouts in the city, and 255 tram stops. The rolling stock consists of several types of trams of different manufacturers, and according to development plans, in several years the ZET tram rolling stock will consist of only three types of tram motor cars: the NT 2200, 2100 and modernized 301 (KT4). The total number of transported passengers by trams in the City of Zagreb amounts to about $182,000,000$ passengers.

Trams are located at two tram depots. The tram depot at Trešnjevka covers $9213.11 \mathrm{~m}$ of rails, out of which 28 are for parking and 87 for turnouts. Every day six types of cars, one type of trailer-car, working and freight trams are prepared for traffic. The tram depot in Dubrava has 8130.98 metres of rails with 27 tracks and 61 turnouts. From this tram depot three types of trams and one type of trailer-car are included in the traffic every day.

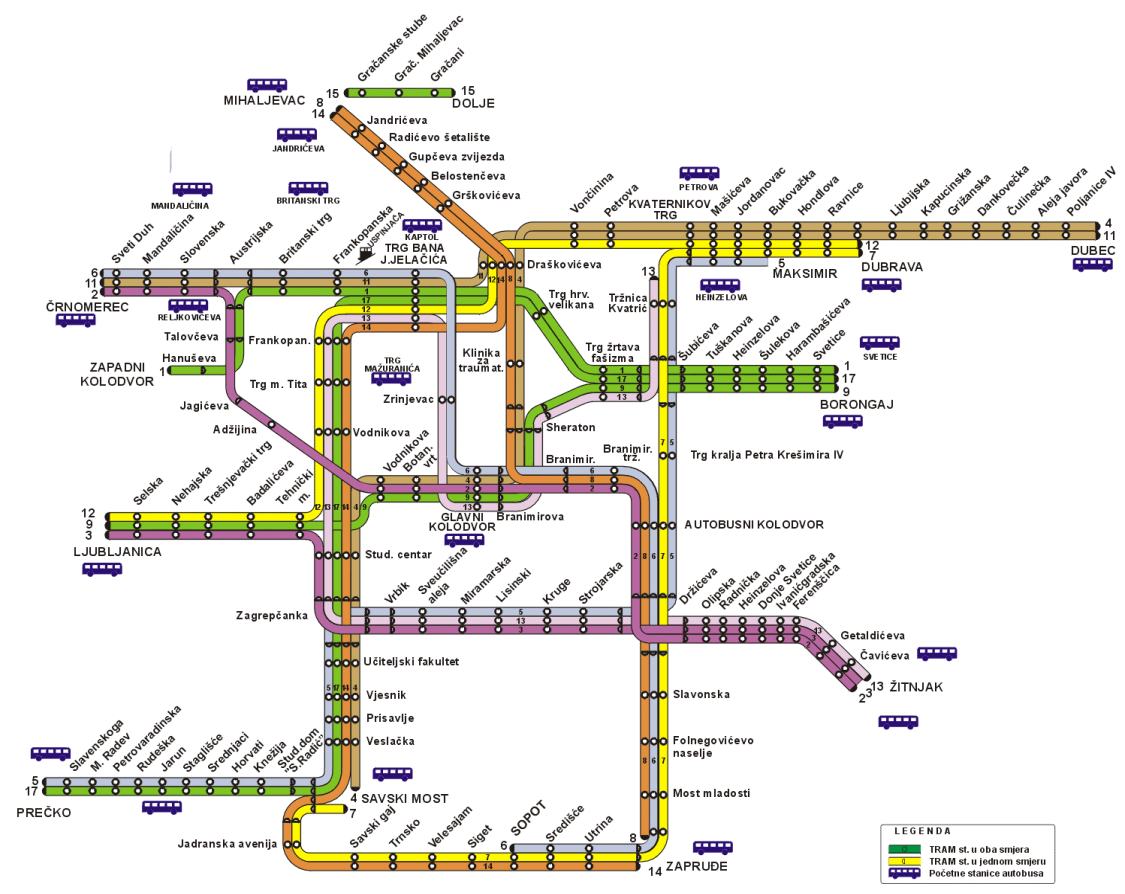

Figure 1: $\quad$ Tram lines network.

\subsection{Bus traffic}

Bus traffic as part of the public urban traffic is organized in the area of the City of Zagreb, and in the areas of the towns of Velika Gorica and Zaprešić, as well as the districts of Bistra, Luka, Stupnik, Klinča Selo and Jakovlje as part of the suburban traffic. The total bus traffic operates on 125 day and four night lines. 
On the ZET bus network (Figure 2) there are in total 1994 bus stops, out of which 1527 are in the area of the City of Zagreb. On the working days 268 buses are distributed on the regular lines, 185 on Saturdays, and 123 buses on Sundays and holidays. The total number of transported passengers annually by ZET buses amounts to about $84,000,000$ passengers.

The rolling stock is standardized and consists of vehicles of MAN make located at the Podsused garage and Mercedes - located at the Dubrava garage. New vehicles are mainly low-floor ones, which make the public urban transport accessible to all categories of users, and a purchase of 200 low-floor vehicles has been planned for the next several years. Since 2007 biodiesel has been introduced as fuel, and compressed gas is to be used from this year. According to development plans, in several years only bio-fuel will be used, which is a great contribution from the public urban transport in the City of Zagreb to the reduction of pollution and elimination of harmful particles contained in fossil fuels.

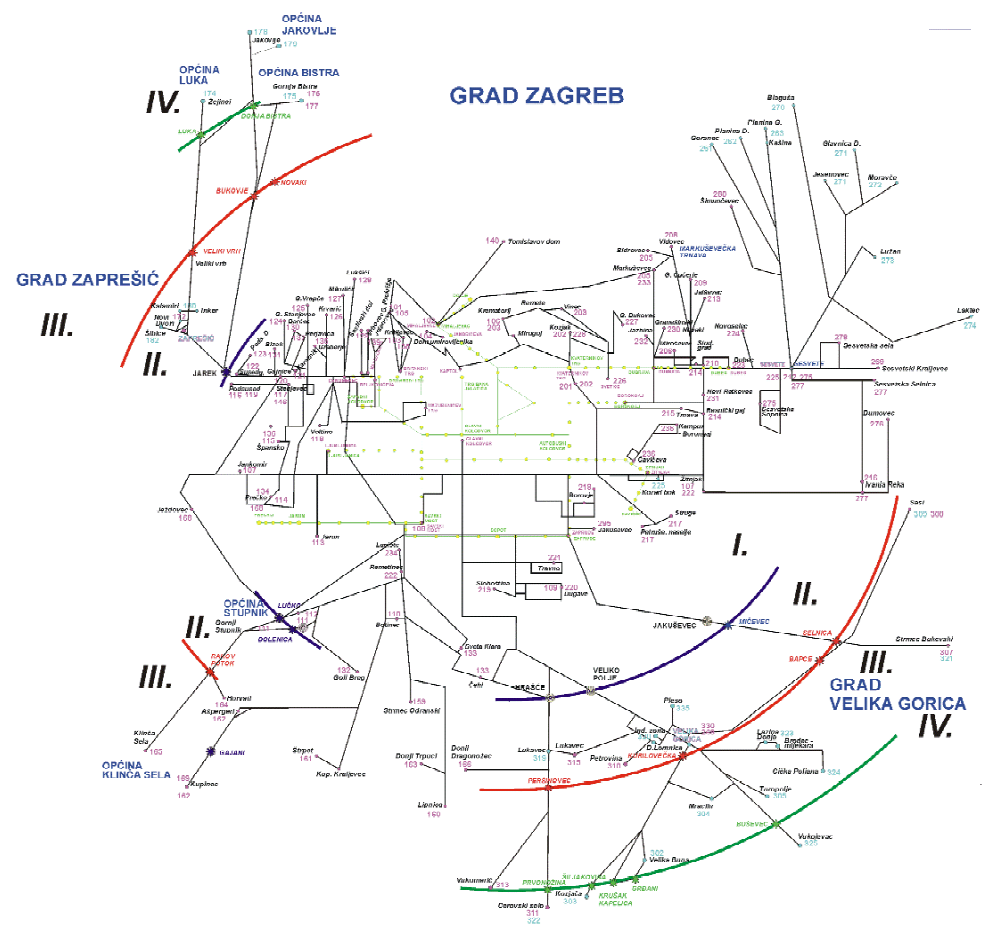

Figure 2: $\quad$ Bus lines network.

\subsection{Rail traffic}

The area of the Zagreb railway junction is surrounded by the City of Zagreb and part of the area of Zagreb County. The junction itself is located at the intersection of two important Pan-European traffic corridors (Corridors $\mathrm{X}$ and 
$\mathrm{Vb}$ ), and therefore it plays an important role in international and internal traffic connections, both of the City of Zagreb, and the Republic of Croatia in general. By passing radially through the City of Zagreb the existing corridors of the railway lines allow good provision of urban and suburban railways that are included in the public transport system in the city, although the current network of lines and stops has not been completely adapted to the requirements of the public urban and suburban railway traffic.

Urban transport by rail covers the area within the Zagreb railway junction, whereas suburban transport by rail covers the Zagreb catchment area, and timewise it is 45-60 minutes ride by train from the city centre (Figure 3). This wider area includes Zagreb County (which surrounds the City of Zagreb) and parts of the neighbouring counties.

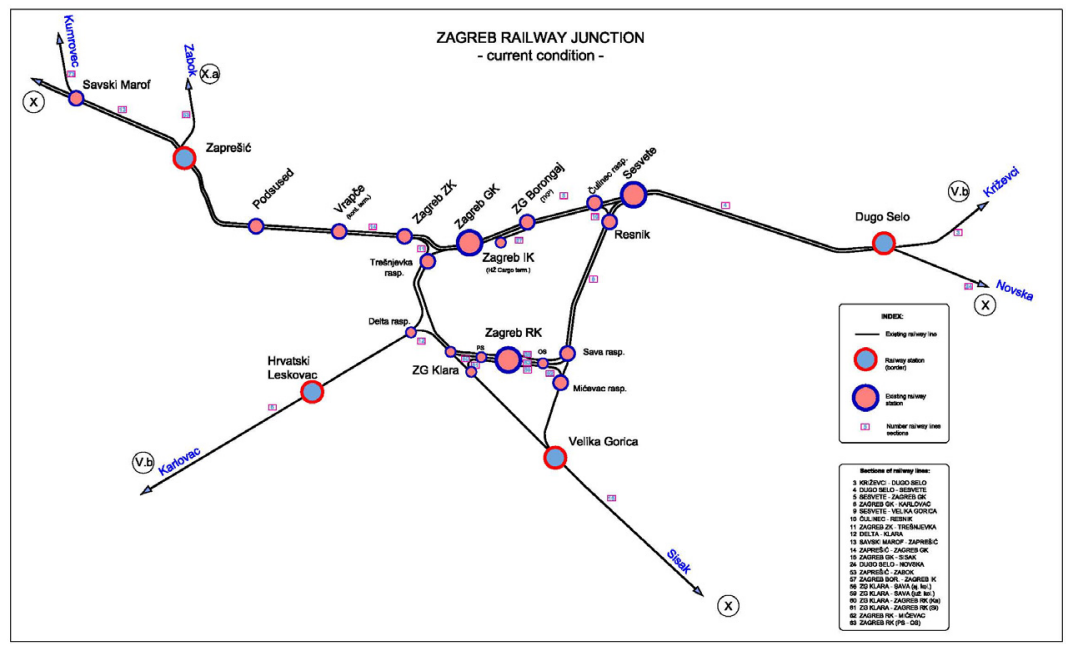

Figure 3: Railway lines operating urban and suburban trains.

Current urban lines are:

- Zagreb GK - Zaprešić

$15.2 \mathrm{~km}$

- Zagreb GK - Savski Marof - Sutla

- Zagreb GK - Dugo Selo

$25.5 \mathrm{~km}$

$20.8 \mathrm{~km}$

The most intensive urban traffic is on the longitudinal line through the city, which extends from Savski Marof, via Zagreb Main Railway Station to Dugo Selo. Apart from the mentioned lines, which are operated by electric railcars, the existing regional trains perform the function of the urban and suburban trains on the lines from Zaprešić to Zagreb and from Dugo Selo to Zagreb. On average about 70,000 passengers use urban-suburban railway transport every working day.

\subsection{Funicular}

The funicular is the oldest transport means of the organized public transport of passengers in the City of Zagreb. With the 66-metre long line, it is the shortest in 
the world. According to the traffic and technical data, its average riding speed amounts to $1.5 \mathrm{~m} / \mathrm{s}$, travel time $64 \mathrm{~s}$, capacity of one cabin is 28 passengers (16 seats and 12 standing places). In spite of its small participation in the total public urban transport, regarding its dimensions (two cars) and location the funicular performs a significant traffic service. On average the cabins travel yearly about $4000 \mathrm{~km}$, with traffic performance of about 118,000 place-kilometres, and carry about 750,000 passengers. Since during more than one century of operation there were no accidents, nor any injured passengers, it represents the safest transport means. To this day it has fully retained its original outer design and construction, as well as the majority of the technical properties given by its designers, and therefore the Zagreb funicular is protected legally as a cultural monument.

\section{Analysis of the current condition of railway traffic as part of public urban and suburban traffic in the City of Zagreb}

The system of urban and suburban traffic operates on the railway infrastructure of the Zagreb railway junction and connection junction lines. Zagreb railway junction is located within the area surrounded by the railway stations Dugo Selo, Velika Gorica, Hrvatski Leskovac and Zaprešić. Zagreb Main Railway Station is the central station of the junction in passenger traffic where the trains on national and international lines start and end their journeys, and some of the trains pass through the railway station. In the area of the Zagreb Main Railway Station all the functions related to technical maintenance, washing, cleaning, and catering, as well as passenger wagon garaging are performed.

The introduction of railways into the system of public urban and suburban traffic of Zagreb has resulted in its complete recognition reflected in the constant increase of the number of trains and transported passengers (Table 2). In the urban-suburban railway transport in Zagreb 10 electric railcar compositions are used, whereas in cooperation with the City of Zagreb a reconstruction of six compositions has been carried out. The section Savski Marof-Dugo Selo is the most frequently used railway line in Croatia, with the highest average travel speed and largest number of transported passengers (Figure 4). Apart from this line, other important suburban lines are towards Velika Gorica and Jastrebarsko, and together with local trains from Zabok, Novska, Karlovac and Koprivnica, $\mathrm{HŽ} \mathrm{offers} \mathrm{a} \mathrm{total} \mathrm{of} 350$ trains daily (condition 2007).

\section{Advantages and possibilities of increasing the share of railways in public urban transport and proposal of the future network of roads in urban and suburban traffic - Zagreb junction}

The basic advantages of railways compared to other transport modes are multiple and the following can be highlighted: safety, all elements of environmental protection, space occupancy, travelling speed, travel time, transport service capacity, mass characteristic, etc. 
Table 2: $\quad$ Main indicators of traffic flow towards sections of railway lines of Zagreb junction.

\begin{tabular}{|c|c|c|c|c|c|c|}
\hline \multirow{2}{*}{$\begin{array}{l}\text { Section / } \\
\text { length }\end{array}$} & \multirow{2}{*}{$\begin{array}{c}\text { Work } \\
\text { indicator }\end{array}$} & \multicolumn{5}{|c|}{ Year } \\
\hline & & 2002 & 2003 & 2004 & 2005 & 2006 \\
\hline $\begin{array}{c}\text { DUGO SELO } \\
\text { - SESVETE } \\
10,2 \mathrm{~km} \\
\end{array}$ & $\begin{array}{c}\text { No. of } \\
\text { passengers } \\
\text { No. of trains }\end{array}$ & $\begin{array}{c}5.128 .502 \\
135 \\
\end{array}$ & $\begin{array}{c}5.231 .497 \\
138 \\
\end{array}$ & $\begin{array}{c}5.594 .254 \\
137 \\
\end{array}$ & $\begin{array}{c}6.128 .596 \\
150 \\
\end{array}$ & $\begin{array}{c}6.500 .995 \\
160 \\
\end{array}$ \\
\hline $\begin{array}{c}\text { SESVETE - } \\
\text { ZAGREB GK } \\
10,6 \mathrm{~km}\end{array}$ & $\begin{array}{c}\text { No. of } \\
\text { passengers } \\
\text { No. of trains }\end{array}$ & $\begin{array}{c}4.861 .983 \\
138\end{array}$ & $\begin{array}{c}4.938 .100 \\
140\end{array}$ & $\begin{array}{c}5.255 .911 \\
140\end{array}$ & $\begin{array}{c}5.758 .591 \\
153\end{array}$ & $\begin{array}{c}6.107 .628 \\
164 \\
\end{array}$ \\
\hline $\begin{array}{c}\text { ZAGREB GK } \\
- \\
\text { KARLOVAC } \\
52,6 \mathrm{~km} \\
\end{array}$ & $\begin{array}{c}\text { No. of } \\
\text { passengers } \\
\text { No. of trains }\end{array}$ & $\begin{array}{c}804.913 \\
31 \\
\end{array}$ & $\begin{array}{c}872.487 \\
30 \\
\end{array}$ & $\begin{array}{c}940.378 \\
29 \\
\end{array}$ & $\begin{array}{c}973.813 \\
27 \\
\end{array}$ & $\begin{array}{c}1.027 .554 \\
35 \\
\end{array}$ \\
\hline $\begin{array}{c}\text { SESVETE - } \\
\text { VELIKA } \\
\text { GORICA } \\
16,4 \mathrm{~km} \\
\end{array}$ & $\begin{array}{c}\text { No. of } \\
\text { passengers } \\
\text { No. of trains }\end{array}$ & $\begin{array}{c}44.946 \\
2 \\
\end{array}$ & $\begin{array}{c}38.399 \\
2 \\
\end{array}$ & $\begin{array}{c}43.555 \\
2 \\
\end{array}$ & $\begin{array}{c}49.469 \\
2 \\
\end{array}$ & $\begin{array}{c}54.060 \\
2 \\
\end{array}$ \\
\hline $\begin{array}{c}\text { SAVSKI } \\
\text { MAROF - } \\
\text { ZAPREŠIĆ } \\
11,6 \mathrm{~km}\end{array}$ & $\begin{array}{c}\text { No. of } \\
\text { passengers } \\
\text { No. of trains }\end{array}$ & $\begin{array}{c}603.861 \\
57\end{array}$ & $\begin{array}{c}643.977 \\
61\end{array}$ & $\begin{array}{c}621.213 \\
57\end{array}$ & $\begin{array}{c}722.216 \\
65\end{array}$ & $\begin{array}{c}801.774 \\
71\end{array}$ \\
\hline $\begin{array}{c}\text { ZAPREŠIĆ - } \\
\text { ZAGREB GK } \\
15,1 \mathrm{~km}\end{array}$ & $\begin{array}{c}\text { No. of } \\
\text { passengers } \\
\text { No. of trains }\end{array}$ & $\begin{array}{c}2.909 .625 \\
107\end{array}$ & $\begin{array}{c}3.173 .993 \\
113\end{array}$ & $\begin{array}{c}3.252 .236 \\
111\end{array}$ & $\begin{array}{c}3.577 .410 \\
121\end{array}$ & $\begin{array}{c}3.960 .360 \\
135\end{array}$ \\
\hline $\begin{array}{c}\text { ZAGREB GK } \\
\text { - SISAK } \\
49,9 \mathrm{~km}\end{array}$ & $\begin{array}{c}\text { No. of } \\
\text { passengers } \\
\text { No. of trains }\end{array}$ & $\begin{array}{c}1.238 .206 \\
25\end{array}$ & $\begin{array}{c}1.550 .811 \\
32\end{array}$ & $\begin{array}{c}1.379 .521 \\
25\end{array}$ & $\begin{array}{c}1.428 .574 \\
26\end{array}$ & $\begin{array}{c}1.539 .232 \\
28\end{array}$ \\
\hline $\begin{array}{c}\text { ZG KLARA - } \\
\text { SAVA J.K. } \\
6,7 \mathrm{~km}\end{array}$ & $\begin{array}{c}\text { No. of } \\
\text { passengers } \\
\text { No. of trains }\end{array}$ & $\begin{array}{c}65.626 \\
1\end{array}$ & $\begin{array}{c}67.186 \\
1\end{array}$ & $\begin{array}{c}74.520 \\
1\end{array}$ & $\begin{array}{c}72.307 \\
1\end{array}$ & $\begin{array}{c}67.692 \\
2\end{array}$ \\
\hline $\begin{array}{c}\text { ZG RK otp.s.- } \\
\text { ZG RK prij.s. } \\
2,7 \text { km }\end{array}$ & $\begin{array}{c}\text { No. of } \\
\text { passengers } \\
\text { No. of trains }\end{array}$ & $\begin{array}{c}53.173 \\
2\end{array}$ & $\begin{array}{c}54.521 \\
2\end{array}$ & $\begin{array}{c}59.058 \\
2\end{array}$ & $\begin{array}{c}57.312 \\
2\end{array}$ & $\begin{array}{c}56.015 \\
2\end{array}$ \\
\hline
\end{tabular}

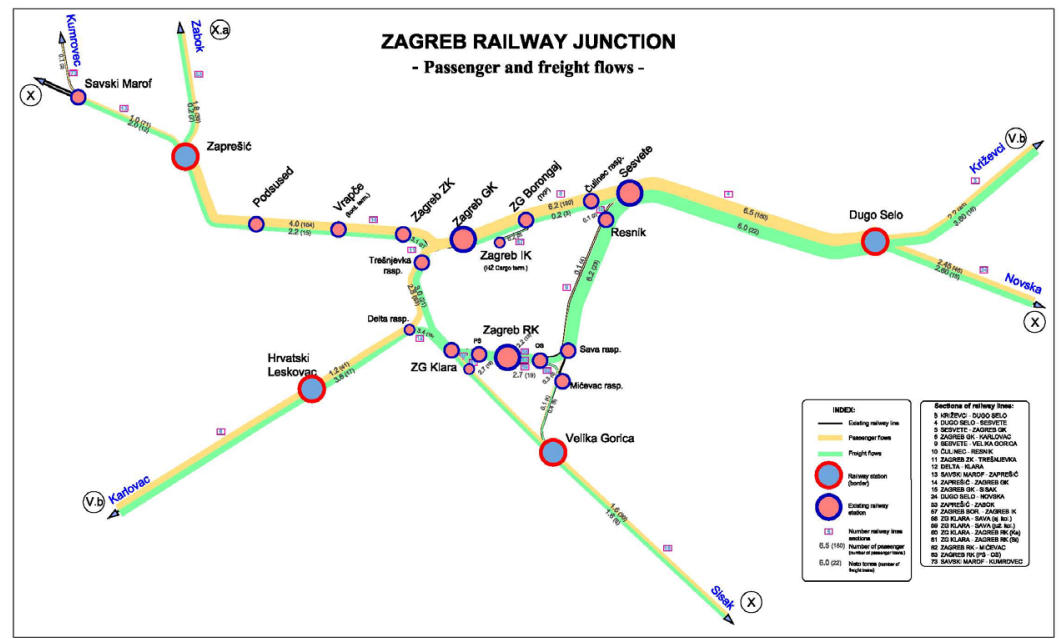

Figure 4: $\quad$ Passenger and freight flows in the ZG junction. 
The railway with its potential has the possibilities of increasing its participation in the system of public urban and suburban transport. This requires redefinition of the Zagreb railway junction, which, apart from infrastructure interventions, would also include interventions in organizational sense, as well as more intensive connection of the railway with other transport modes (bus and tram) into an integrated whole.

The future solution of the Zagreb railway junction includes the interventions in infrastructure necessary to perform the planned future traffic through the junction. The junction lines of Pan-European significance have to provide capacities and equipment that meet the required criteria, i.e. they have to be eventually double-gauge, electrified, equipped with modern systems for regulation and management of traffic. This will allow also a more intense suburban traffic, which also requires the construction of two more tracks intended exclusively for urban and suburban traffic on the section of the railway network in the city (East-West direction) along the existing double-track line. Construction of new stops (Avenija Vukovar, Savski most, Trokut and Buzin, reconstruction of stops Remetinec and Odra) and construction of platforms (at railway stations Velika Gorica, Zagreb Klara and Hrvatski Leskovac), are planned in the area of the city and on the connection lines of the junction in order to adapt their number to the passengers' requirements.

In order to include the capacity and equipment of the lines in the junction and on the connection lines of the junction as efficiently as possible into the urban and suburban traffic of the City of Zagreb, the construction of new lines is necessary since they should relieve the existing traffic network of the city on the busiest lines. As part of fast urban railways, two new lines have been proposed, which connect the south part of the city (direction from Velika Gorica and Zagreb Airport) and the south-western part of the city (settlements Jarun, Prečko) [2].

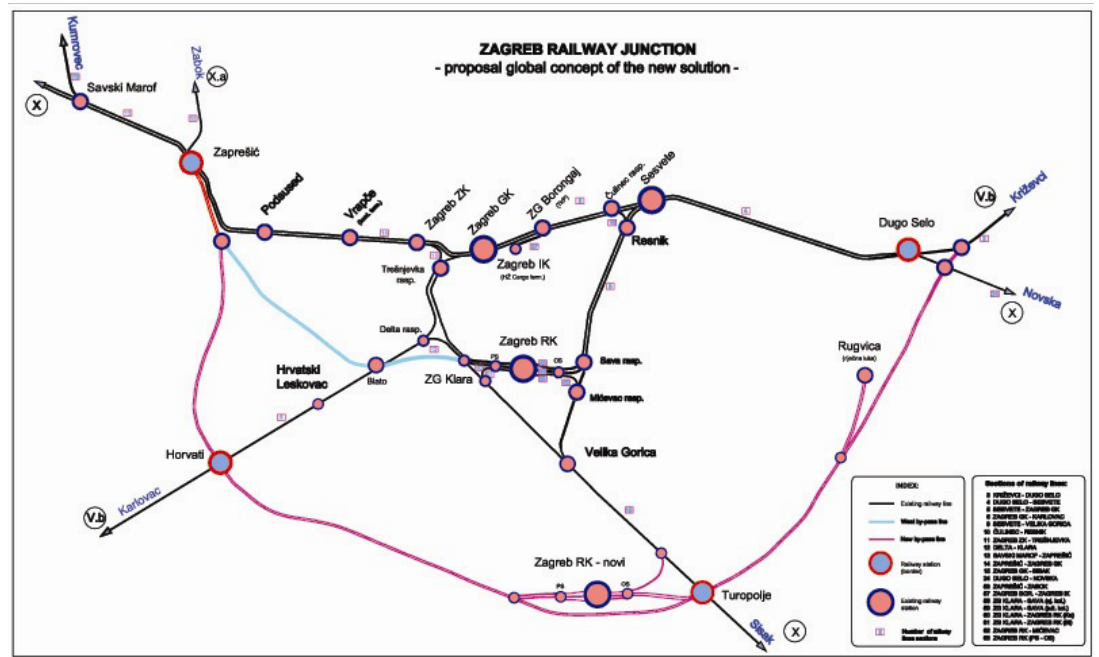

Figure 5: Proposal of global concept of the new solution. 
With the proposed solution (Figure 5) the railway capacities would cover well the area of the city and the surroundings, and the railway could become the backbone of the goods and passenger transport. The only part that remains not covered is the central area of the city from the airport to the new cable car on the Medvednica mountain, where the construction of the new traffic system is possible (overground or underground).

The traffic and technological assumptions of the proposed new concept solution of railway traffic in the Zagreb junction can be divided into three groups [5]:

1. Reconstruction and extension of the existing lines

- Railway line Zaprešić - Zagreb GK - Dugo Selo

- Railway line Zagreb GK - Karlovac

- Railway line Zagreb GK - Sisak

2. New railway lines as part of the Zagreb railway junction

- West by-pass line Savski Marof - Blato - Zagreb RK

- Railway line Podsused - Samobor - Bregana [1]

- New by-pass line Zaprešić - Hrvatski Leskovac - Turopolje - Dugo Selo

- Railway line Velika Gorica - Pleso (airport)

- Railway line Turopolje - Rugvica (river port)

- Other connection railway lines

3. Reconstruction and modernization of railway stations

- Zagreb Main railway station - centre of passenger traffic

- Disposition of urban and suburban traffic stops

- Zagreb shunting station - centre of freight traffic

- Zagreb West Railway Station - role in the new concept

- Railway freight terminal - replacement for Zagreb East Railway Station

- Freight-distribution centre and container terminal

- Capacities for the maintenance of transport means

According to the new conceptual solution of the railway junction, the lines intended for passenger traffic cover well the area of the city and suburban settlements (radial connection of the city centre with the suburban areas), and the new by-pass line which is primarily intended for freight traffic, is completely moved out of the urban area.

\section{Concluding considerations}

The existing network of railway lines and stations is not completely adapted to the needs of public urban and suburban railway traffic and it needs to be supplemented and modernized in order to raise the level of service, so that the railways could play the dominant role in suburban traffic. This primarily refers to the reconstruction and upgrading of railway lines and stations, and purchase of new, modern transport means. Besides, along with the modernization of infrastructure and transport capacities, also the modernization and organization of passenger transport in urban and suburban traffic is necessary by introducing advanced traffic management systems, as well as by introducing the system of unique tariff union that would integrate all modes of public transport (rail-bustram). 
Using this concept, the traffic system in the City of Zagreb has been based on the railway capacities and technology, thus making railway the backbone of public urban and suburban passenger transport.

\section{References}

[1] Construction of railway tracks on section Podsused tv. - Samobor Bregana, Investment study, Institute of Transport and Communications, Zagreb, 2003.

[2] General Urban Plan, The City of Zagreb Official Courier, 10/2007

[3] Statistics of Croatian Railways, Zagreb, 2008

[4] Statistics of ZET - Zagreb Electrical Tram, Zagreb, 2008

[5] Study of the rail-road transport system in Zagreb area - Conception solution of railway transport, Draft version, Institute of Transport and Communications, Zagreb, 2008. 